\title{
Case Study Of Employee Turnover At Ice Cream Deli In Mexico
}

Lorena Hernández von Wobeser, Universidad del Caribe, México Graciela Ramírez Escamilla, Universidad del Caribe, México

Irmgard von Wobeser, Von Wobeser Human Consulting, SC, México

\begin{abstract}
This case study focuses on a Mexican franchise - "Ice Cream Deli" - and its interest to reduce voluntary-avoidable turnover in order to lower costs and increase productivity. High turnover is a common problem in many organizations in Cancun and Playa Del Carmen, Mexico. The ten "Ice Cream Deli" stores studied in this case present a high voluntary turnover, even when the job conditions in the organization are better than the market. Arturo Mendoza, Director of Operations, is interested in analyzing the root causes of the problem and providing an action plan to reduce turnover of line workers. Some of the reasons for turnover and retention are stated from the perspective of the workers.
\end{abstract}

Keywords: Employee Turnover; Employee Retention; Productivity; Desirable Turnover; Avoidable Turnover

\section{INTRODUCTION}

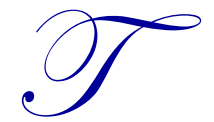

urnover (the percentage of employees leaving the organization) is a very common problem in organizations. Managers measure turnover by the "turnover rate" calculated by "the total number of employees leaving the organizations during the month divided by the average number of employees during the month". (Phillips, 2003) Although achieving zero percent turnover is "neither realistic nor desirable" (Branham, L. 2000, p.5), many academic and business specialists in the area suggest tools to reduce turnover effectively in order to lower costs and increase productivity.

In the first section of this paper, an overview is presented of some of the main causes for turnover, including the strategies to reduce it, according to three contemporary authors. A description of "Ice Cream Deli" in Cancun and Playa del Carmen is included also, as well as the interest of their Director of Operations, to maintain stability in human resources and optimize organizational productivity.

Finally, in the last section, the three methodologies applied to analyze the root causes of voluntary turnover $^{1}$ and the main causes of organizational retention are presented: 1) Gallup Q-12 Survey, 2) Nominal Technique, and 3) Appreciative Inquiry toward Retention. Some of the reasons for turnover and retention in "Ice Cream Deli" are expressed from the perspective of the workers and summarized in figures.

\section{THEORY OVERVIEW}

\section{Negative Impact of Turnover in the Organization}

Even though some amount of turnover is generally considered as healthy, sometimes "the wrong people do stay, while the right people leave". (Branham, 2000, p. 5-6) This turnover has a negative impact for the organization which invested time and money in recruitment, selection, hiring, training, and in the development of talent.

\footnotetext{
${ }^{1}$ Voluntary turnover (which is avoidable) means that the employee has decided to leave the organization because of his own reasons, and an involuntary turnover (which generally is not avoidable) is when an employee leaves the organization against his will (a disease, moving to another city, an accident, or lack of time, among others).
} 
Some of the negative impacts of turnover in the organization are high financial costs, exit problems, productivity losses, negative impact on customer service, loss of expertise, loss of business opportunities, administrative problems, disruption of social and communication networks, job dissatisfaction of remaining employees, as well as a bad image of the organization. (Phillips, 2003, p. 5-6)

\section{Why Reduce Turnover?}

The antidote to high turnover is retention - "the process of attracting, selecting, caring about, training, developing, and keeping a workforce so that it can perform its jobs in an organization". (Smith, 2004, p.19) Retention matters for three important bottom-line reasons: 1) the growing importance of intellectual capital, 2) a causal link between employee tenure and customer satisfaction, and 3) the high cost of employee turnover. (Harvard Business Essentials, 2002, p. 60)

According to Smith (2004, p.24), the first reason to practice retention is cost: "Even a small effort can save plenty of money. Studies show that at a minimum, it costs $\$ 4,000$ to $\$ 7,000$ to replace an hourly low-wage employee and up to \$40,000 to replace a mid-level salaried employee”. (Smith, 2004, p. 20)

Productivity is also an important reason to practice retention programs; "Productivity and retention go hand in hand. Improve one, and you improve the other." (Smith, 2004, p. 24)

\section{Causes of Turnover and Retention Strategies}

According to Branham (2000, p. 5), people move on from organizations for "a variety of unpreventable reasons - more money, better benefits, the appearance of greener pastures, partner relocation, the desire to be a full-time parent, to retire, to return to college, and so on."

Some contemporary authors, such as Phillips and Connell (2003), Smith (2004), and Branham (2005), provide different explanatory constructs when looking at turnover. Exhibit A presents a synopsis of these three authors' points of view regarding the Causes of Turnover and Retention Strategies.

Exhibit A: Causes of Turnover and Retention Strategies (Review of Three Contemporary Authors)

\begin{tabular}{|c|c|c|}
\hline Author (S) & Causes of Turnover & Retention Strategies \\
\hline $\begin{array}{l}\text { Phillips, J. and } \\
\text { Connell, A. (2003) }\end{array}$ & $\begin{array}{ll}\text { External drivers } \\
\text { - } & \text { Economic growth } \\
\text { - } & \text { Slower growth of job seekers } \\
\text { - } & \text { Unemployment rate at low levels } \\
\text { - } & \text { Enortage of special skills } \\
\text { - } & \text { Job changes for more favorable climates } \\
\text { Internal Drivers } \\
\text { - } & \text { Lack of company loyalty } \\
\text { - } & \text { Desire for challenging and useful work } \\
\text { - } & \text { Need for autonomy, flexibility and } \\
\text { - } & \text { independence } \\
\text { - } & \text { Need for performance-based rewards } \\
\text { - } & \text { Desire for all types of benefits } \\
\text { - } & \text { Need to learn new skills } \\
\text { - } & \text { Career growth in all directions } \\
\text { - } & \text { Desire to be on the leading edge } \\
\text { - } & \text { Desire for competitive compensation } \\
\text { - } & \text { Need for a caring, supportive environment } \\
\text { - } & \text { Need for work/life balance }\end{array}$ & $\begin{array}{ll}\text { - } & \text { Solution set: recruiting new employees } \\
\text { - } & \text { Solution set: establishing an appropriate work } \\
\text { - } & \text { Solution set: creating equitable pay and } \\
\text { - } & \text { performance processes } \\
\text { colution set: building motivation and } \\
\text { commitment }\end{array}$ \\
\hline
\end{tabular}




\begin{tabular}{|c|c|c|}
\hline Smith, G. (2004) & $\begin{array}{ll}\text { - } & \text { Fewer workers, better times. } \\
\text { - } & \text { Higher expectations of workers } \\
\text { - } & \text { Longer hours, more demanding work } \\
\text { - } & \text { Family demands } \\
\text { - } & \text { A new new class of graduates } \\
\text { - } & \text { Challenge: meeting the needs of an } \\
& \text { increasingly diverse workforce }\end{array}$ & $\begin{array}{l}\text { The } 8 \text { elements of the High-Retention Organization: } \\
\text { 1. A clear sense of direction and purpose } \\
\text { 2. Caring management } \\
\text { 3. Flexible benefits and schedules adapted to the } \\
\text { need of the individual } \\
\text { 4. Open communication } \\
\text { 5. A charged work environment } \\
\text { 6. Performance management } \\
\text { 7. Reward and recognition } \\
\text { 8. Training and development }\end{array}$ \\
\hline $\begin{array}{l}\text { Branham, L. } \\
(2005)\end{array}$ & $\begin{array}{l}\text { 7 Hidden Reasons Employees Leave: } \\
\text { 1. The job or workplace was not as expected } \\
\text { 2. The mismatch between job and person } \\
\text { 3. Too little coaching and feedback } \\
\text { 4. Too little growth and advancement } \\
\text { 5. Feeling devaluated and unrecognized } \\
\text { 6. Stress from overwork and work-life } \\
\text { 7. Loss of trust and confidence in senior } \\
\text { leaders }\end{array}$ & $\begin{array}{l}\text { - } \quad \text { Match expectations with reality } \\
\text { - } \quad \text { Select the right talent for the job } \\
\text { - } \\
\text { - } \quad \text { Provign the right task to the right person } \\
\text { Provide career advancement and growth } \\
\text { - } \quad \text { Makportunities } \\
\text { - } \quad \text { Reduce stress from work-life imbalance and } \\
\text { - } \quad \text { Inspire trust and confidence in senior leaders }\end{array}$ \\
\hline
\end{tabular}

Source: Casewriters

\section{CASE SCENARIO}

\section{Context of High Turnover in Cancun and Playa Del Carmen}

Cancun and Playa del Carmen are two cities in the Caribbean region that are dependent on tourism in Mexico. Turnover levels in Cancun and the Riviera Maya are very high. Even though there is no research about the phenomena, many general managers and HR managers complain about high turnover and the impact on their organizations. Some unexplored hypotheses of the reasons for high turnover are:

- $\quad$ Fast economic growth combined with a slower growth of job seekers

- High migration of job seekers who return to their hometowns after a period of time

- General bad conditions in the job market (very demanding job schedules, low salaries, and bad relationships with supervisors)

- $\quad$ Lack of job benefits such as social security, Christmas bonus, and paid vacations

- $\quad$ Lack of job security because of the desirable turnover due to the low season in tourism. In order to assure the financial stability of the organization during low season, most managers have to make some workers redundant or make high season contracts. There are two periods of low season in these cities: $16^{\text {th }}$ April$10^{\text {th }}$ July and $15^{\text {th }}$ September- $19^{\text {th }}$ December (because of hurricane season in the Caribbean Sea).

\section{"Ice Cream Deli" Organization}

The organization studied in this case is a Mexican franchise - "Ice Cream Deli" - located in the Southeast of Mexico. "Ice Cream Deli" is a premium brand that provides natural-made ice cream, coffee, and beverages with an added value in service. This paper studies ten stores that are well located in shopping centers catering to tourists and on some main streets of the two cities:

- $\quad$ Four stores are located in the city of Playa Del Carmen (Playa 1, Playa 2, Playa 3, and Playa 4).

- Six stores are located in Cancun City (Cancun 1, Cancun 2, Cancun 3, Cancun 4, Cancun 5, and Cancun 6).

\section{"Ice Cream Deli" Case}

The main problem of this case study is the high voluntary-avoidable turnover rate ${ }^{2}$ in the organization. The

\footnotetext{
${ }^{2}$ Avoidable turnover rate: "Avoidable" turnover is distinguished from "unavoidable" so that the proper emphasis can be placed on the avoidable portion. (Phillips, 2003, p.2)
} 
organization presents some desirable turnover ${ }^{3}$ in low season - desirable due to the decrease in sales. It also shows a not desirable turnover ${ }^{4}$ which impacts negatively on productivity, service, and costs. After a brief time, but once the organization has invested in them in the form of training, uniforms, supervision time, and salaries, among others, line workers often leave the organization for no apparent reason.

With the goal to reduce costs and increase productivity, the Director of Operations, Arturo Mendoza, has to work in order to analyze the root causes of the problem and provide an action plan to reduce turnover of the line segment. Arturo Mendoza contacted the consulting firm, "Von Wobeser Human Consulting", to analyze, with objectivity and neutrality, the causes of the turnover. Irmgard von Wobeser, the Senior Consultant, gathered a team of two internship students from "Universidad Del Caribe" supervised directly by Professor Lorena Hernández from the Department of Economy and Business. Within a period of two months, a team of six professionals worked in order to explore the causes of turnover and retention in the organization - Arturo Mendoza (Director of Operations, Ice Cream Deli), Esteban Trejo (HR manager, Ice Cream Deli), Irmgard von Wobeser (Senior Consultant), Lorena Hernández (Professor), Erick Roa (Internship Student), and Angel Gabriel Hernández (Internship Student).

\section{METHODOLOGY TO RESEARCH TURNOVER AND RETENTION IN “ICE CREAM DELI”}

From a list of sixteen tools to diagnose turnover problems presented by Phillips and Connell (2003, p. 29), the Senior Consultant, Irmgard von Wobeser, and her team, decided to use three - Gallup Organization Q12, Nominal Group Technique, and Appreciative Inquiry Interview for Retention.

In each "Ice Cream Deli" store, a two-hour session was conducted by the consultants with all the line workers mainly to obtain non-threatening information about the causes of turnover. A brief definition of the three methodologies is described below:

\section{Gallup Organization Q-12}

In order to start the working sessions, a Q-12 survey with a 1-10 scale was applied to line employees. But, what is the Gallup Organization Q-12 survey about? The Gallup organization published a mayor study involving thousands of employees, in which 12 questions were identified as being linked to employee turnover in some way. These questions, (shown in Exhibit B) are powerfully connected to turnover in many organizations. The research shows that questions 1, 2, 3, and 5 manifest the strongest direct relationship to turnover. (Phillips, 2003, p. 96-97)

\section{Exhibit B: Q12 According To Gallup}

1. Do I know what is expected of me at work?

2. Do I have the materials and equipment I need to do my work right?

3. At work, do I have the opportunity to do what I do best every day?

4. In the last 7 days, have I received recognition or praise for doing good work?

5. Does my supervisor, or someone at work, seem to care about me as a person?

6. Is there someone at work who encourages my development?

7. At work, do my opinions seem to count?

8. Does the mission/purpose of my company make me feel my job is important?

9. Are my co-workers committed to doing quality work?

10. Do I have a best friend at work?

11. In the last 6 months, has someone at work talked to me about my progress?

12. This last year, have I had opportunities at work to learn and grow?

Source: Buckingham and Coffman, 1999

\footnotetext{
${ }^{3}$ Desirable turnover: Not all turnover is bad. There is a desirable turnover, for example, when employees have weak performance, lack of skills, bad attitude, or dishonest behavior, among others.

${ }^{4}$ Not desirable turnover: This turnover is negative and undesirable for the organization; for example, when the person is a top performer, important for the job, or has valuable experience (know-how), among others.
} 


\section{Nominal Group Technique}

After applying the Q12 survey, a consultant guided a Nominal Group Technique, a semi-structured small group interview. As indicated by Phillips (2003), de Nominal Group Technique was used to ask line employees the reason they believe "others" would leave the organization. "Perhaps one of the most useful and productive tools to determine the causes of turnover is to use a modified focus group process called the Nominal Group Technique. With this process, a group of employees is asked to provide information on why their colleagues are leaving the organization. The key issue is to focus on the reasons why others would leave and not why they would leave. This repositions the data collection from a potentially threatening to a nonthreatening environment. The recommended audience is a representative sample of the target groups experiencing the highest turnover. The group size should be 8 to 12". (Phillips, 2003, P. 113-114)

\section{Appreciative Inquiry Interview}

Analyzing the causes of turnover is important, but also analyzing the causes of retention is significant too. "What keeps you? [...] Have you ever asked your employees what keeps them at your company?" (Kaye, 2004, p. 5) Asking that question can reveal very important information about the actions "Ice Cream Deli" could continue doing in order to achieve better personnel retention.

"Appreciative Inquiry" methodology, guided by David Cooperrider and his team in Case Western Reserve University, support the idea that whatever you inquire about has a real effect in organizations. If someone asks a group of people why they leave an organization, this might influence people's perspectives to see the negative aspects in the organization and their shared answers would probably suggest the idea of leaving the organization by themselves. This is one of the reasons why Appreciative Inquiry authors invite the organization and their executives to ask positive questions about the topic they want to know more about.

Appreciative Inquiry is about the co-evolutionary search for the best in people, their organizations, and the relevant world around them. [...] AI (Appreciative Inquiry) involves, in a central way, the art and practice of asking questions that strengthen a system's capacity to apprehend, anticipate, and heighten positive potential. (Cooperrider, 2000, p. 5)

In order to reduce the negative effect of using the Q12 Methodology and Nominal Technique Methodology (Why you don't like your organization), the consultants decided to close the work session with a brief Appreciative Inquiry interview in order to focus on the opposite (What do you like more about your organization?). All the participants were assigned in pairs in order to interview each other with a simple interview guide. The two main questions of the interview guide were:

1. What keeps you working at "Ice Cream Deli"?

2. What should happen to inspire you to continue working at "Ice Cream Deli"?

\section{“ICE CREAM DELI" RESULTS}

Using the three methodologies described earlier, the line workers had the opportunity to communicate the main reasons for turnover and retention.

\section{Gallup Organization Q-12 Results}

Exhibit C presents the results of Q12 using a 1-10 scale (1 means "strongly disagree" and 10 means "strongly agree") and the outcome is presented from better to worst. According to the results, the line workers perceive some strength in the organization, such as clear goals, caring from direct supervisor/friends, and use of talent at work. On the other hand, they report some issues that probably affect turnover - lack of recognition, feedback, and career growth. 
Exhibit C: Q12 Inquiry Results for "Ice Cream Deli"

Ordered From The Best Results (10 Points-Strongly Agree) To The Worst Results (1 Points-Strongly Disagree)

\begin{tabular}{|c|l|}
\hline Results & \multicolumn{1}{c|}{ Number of Question/Questions } \\
\hline 9.03 & 1. Do I know what is expected from me at work? \\
\hline 8.73 & 5. Does my supervisor or someone at work seem to care about me as a person? \\
\hline 8.42 & 3. At work, do I have the opportunity to do what I do best every day? \\
\hline 8.40 & 6. Is there someone at work who encourages my development? \\
\hline 8.36 & 7. At work, do my opinions seem to count? \\
\hline 8.30 & 9. Are my co-workers committed to perform quality work? \\
\hline 7.75 & 2. Do I have the materials and equipment I need to do my work right? \\
\hline 7.73 & 8. Does the mission/purpose of the company make me feel my job is important? \\
\hline 7.68 & 12. This last year, have I had opportunities at work to learn and grow? \\
\hline 7.66 & 10. Do I have a best friend at work? \\
\hline 7.55 & 11. In the last 6 months, has someone at work talked to me about my progress? \\
\hline 7.18 & 4. In the last 7 days, have I received recognition or praise for doing my work well? \\
\hline
\end{tabular}

Source: Casewriters

The result of Q12 by stores (Exhibit D) indicates differences between stores. Stores from Playa del Carmen had better results than stores in Cancun. The best store was "Playa 1" with 9.1 punctuation and the worst was "Cancun 5" with 7.2.

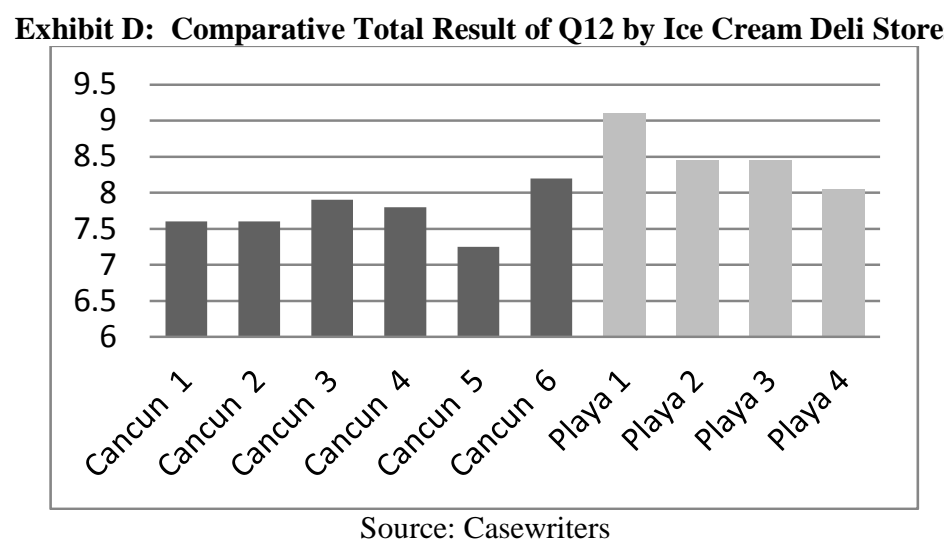

\section{Nominal Group Technique Results}

The question "Why others quit the organization" provides very interesting answers to enlighten turnover at "Ice Cream Deli". Answers to a brainstorm activity with the line workers were evaluated by themselves with the following scale: 3 points (the most important reason), 2 points (medium importance), and 1 point (less importance). The total results were added and are presented in Exhibit E. 
Exhibit E: Reason "Others" Quit "Ice Cream Deli"

\begin{tabular}{|l|c|l|c|}
\hline Reasons why "Others" Quit the Organization & Points & \multicolumn{1}{c|}{$\begin{array}{c}\text { Reasons why "Others" Quit the Organization } \\
\text { (continue) }\end{array}$} & Points \\
\hline Expectations of Better Pay & 168 & Abuse of Authority & 20 \\
\hline Lack of Job Security & 78 & Sexual Harrassement from direct Supervisors & 19 \\
\hline Desire for Career Growth & 73 & Robbery* & 18 \\
\hline Demanding Work Schedule & 51 & Lack of Values & 16 \\
\hline $\begin{array}{l}\text { Favoritism and Friends from Owners in } \\
\text { Organization }\end{array}$ & 46 & Bad Communication with Senior Leaders & 13 \\
\hline Desire of Recognition from Senior Leaders & 44 & Lack of Skills for the Job* & 10 \\
\hline Desire for more Training Programs & 34 & Bad communication with Employees & 10 \\
\hline Problems with Supervisor* & 32 & Fear of Freedom of Speech & 6 \\
\hline Better Job Opportunities & 30 & Irresponsability * & 6 \\
\hline Charging employees for Lost Stock & 29 & Cut of Previous Benefits (Free Ice Cream) & 6 \\
\hline Personal Difficulties from out of the Job* & 22 & Strict Hygiene Standards from the Organization & 6 \\
\hline Low investment in Human Resources & 20 & Decreasing Motivation Level & 3 \\
\hline
\end{tabular}

(*) Probably involves "involuntary turnover" or "desirable turnover"

Points were calculated adding the punctuation evaluated in the 10 stores. Higher punctuation means a stronger perceived reason why others leave the organization voluntarily or involuntarily. It also describes the implicit reason of why workers might leave the organization in the near future.

Source: Casewriters

\section{Appreciative Inquiry Interview Results}

Finally, Exhibit $\mathrm{F}$ presents the results of the Appreciative Inquiry Interview notes. The team of consultants transcribed the notes from the interviews and made a qualitative categorization of the concepts. Later, every category was counted for every time it appeared in the notes. ${ }^{5}$

For the first question, "What keeps you working in 'Ice Cream Deli'?" (Exhibit F-a), the two most popular answers were job environment (42\%) and good relationship with peers (28\%).

For the second question, "What should happen to inspire you to continue working in 'Ice Cream Deli'?" (Exhibit F-b), the two most popular answers were career development and growth opportunity (28\%) and job security $(21 \%)$.

Exhibit F: Causes of Retention in "Ice Cream Deli"

a) What keeps you working in "Ice Cream Deli"?

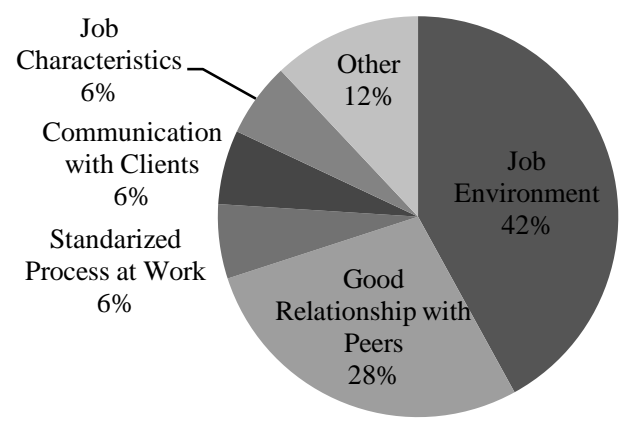

\footnotetext{
${ }^{5}$ Note: Quantification of answers is not a practice recommended by the Appreciative Inquiry Methodology, but case writers decided this could be a practical way to include a synthesis of the information regarding the topic talked during the interviews for the Case Study. (There are at least 3 pages of transcription for each line worker interviewed).
} 
b) What should happen to inspire you to continue working at "Ice Cream Deli"?

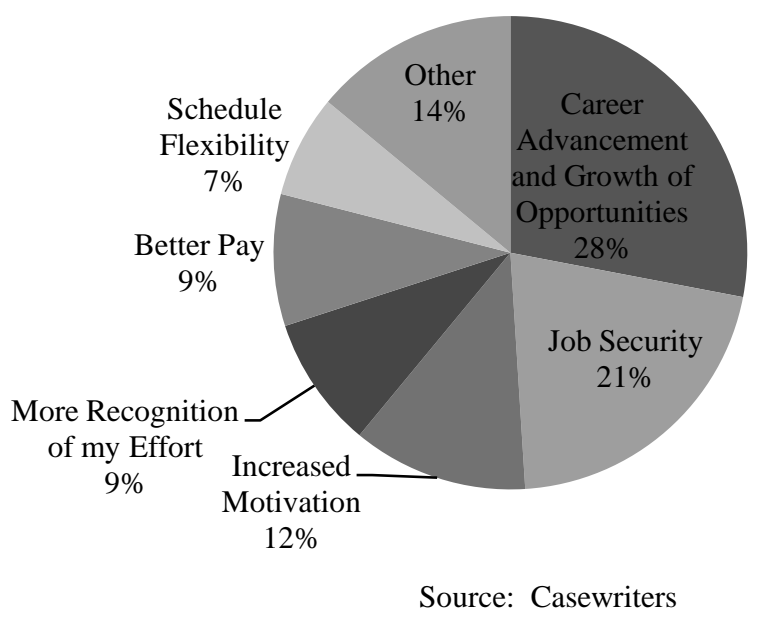

\section{CONCLUSION}

Even though high turnover rates is a common problem in Cancun and in Riviera Maya due to economic growth, social migration, high-low tourist seasons, and organizational issues in the area, organizations can apply retention strategies in order to lower their undesirable turnover rates and benefit both their organizations and their personnel. The first step to the application of retention strategies is to identify possible causes of turnover.

The results of turnover studies in "Ice Cream Deli" provided information about the interest and aspirations of line workers. Some of the possible causes of turnover reported by the line workers were:

- $\quad$ Expectations of better pay

- Lack of recognition

- $\quad$ Lack of job security

- $\quad$ Limited opportunity of career growth

- $\quad$ Demanding work schedule

On the other hand, "Ice Cream Deli" has strengths that increase retention, such as:

- $\quad$ Great job environment

- $\quad$ Good relationship with peers

- Clear goals

"Ice Cream Deli" stores in Playa Del Carmen received better results than stores in Cancun. Consultant hypothesis of this difference is that Playa del Carmen's stores have better sales than the ones in Cancun, and this is highly motivational. The other hypothesis is due to the supervisor of the zone because Cancun and Playa del Carmen have different supervisors; however, more research to confirm either of these hypotheses is needed.

\section{AUTHOR INFORMATION}

Lorena Hernández Von Wobeser is Professor of Organizational Psychology at Universidad del Caribe, CancúnMéxico. She has a Master's degree in Business from the ITESM, Campus Ciudad de México and she has a combination of academic and business experience. Contact with the author is encouraged and welcomed. She can be reached at lhvon@ucaribe.edu.mx (Corresponding author) 
Graciela Ramirez Escamilla is an English Professor at Universidad del Caribe, Cancún-México and is currently studying for a Master's degree in "Administración de Instituciones Educativas" with the ITESM Virtual University, Campus Hidalgo, Mexico. gramirez@ucaribe.edu.mx

Irmgard Von Wobeser Hoepfer is a Consultant in Human Resources with her own consulting firm - Von Wobeser Human Consulting, SC. She is a Psychologist with more than 25 years of experience in academics and business. She can be reached at irmgard@ vwhconsulting.com

\section{REFERENCES}

1. Branham, Leigh (2000). Keeping the People Who Keep You In Business. 24 Ways to hang on to your most valuable Talent. New York: AMACOM p. 338.

2. $\quad$ Branham, Leigh (2005). The 7 Hidden Reasons Employees Leave. New York: AMACOM. p. 238.

3. Coffman, C., and Gonzalez-Molna, G. (2002) Follow this Path: How the World's Greatest Organizations Drive Growth by Unleashing Human Potential. New York: Warner Books.

4. Cooperrider, David; Sorensen, Peter; Whitney, Diana. And Yaeger, Therese. (2000) Appreciative Inquiry. Rethinking Human Organization Toward a Positive Theory of Change. USA: Stipes Publishing. P. 287.

5. Griggeth, Roger and Hom, Peter. (2004) Innovative Theory and Empirical Research on Employee Turnover. USA: A volume in Research in Human Resource Management. P. 256.

6. Harvard Business Essentials (2002) Hiring and Keeping the Best People. Boston: Harvard Business School Publishing Corporations. P. 170.

7. Kaye, Beverly and Jordan-Evans, Sharon. (2004). Love'em or Lose'em. Getting good People to Stay. 26 Engagement Strategies for Busy Managers. San Francisco: Berrett-Koehler Publishers. P. 277.

8. Mobley, William (1982) Employee Turnover: Causes, Consequences, and Control. USA: Addison-Wesley Publishing Company. P. 212.

9. Smith, Gregory (2004) Here Today, Here Tomorrow. Transforming your Workforce from High-Turnover to High-Retention. USA: Chart Your Course Publishing Company. P. 250.

10. Phillips, Jack and Connell, Adele (2003). Managing Employee Retention. A Strategic Accountability Approach. USA: Elsevier Buthterworth Heinemann. P. 352.

11. West, Mindy. (2004) Investigate Turnover in the International Context. A Turnover Model for the Mexican Culture. On Griffeth, Roger and Hom, Peter. Innovative theory and Empirical Research on Employee Turnover. A Volume in Research in Human Resource Management. USA: Information Age Publishing. P. 256. 


\section{TEACHING NOTES}

\section{Case Synopsis}

This case study focuses on a Human Resource problem at "Ice Cream Deli" México - high voluntary turnover. Teachers and students can use this case to understand some central issues of the topic, such as definition of turnover and its causes, retention strategies, and some methodologies to evaluate the reasons for turnover and retention.

\section{Learning Objectives}

The specific teaching objectives of the case are:

- $\quad$ to review two methodologies to evaluate causes of turnover

- $\quad$ to apply one methodology to evaluate causes of retention

- $\quad$ to discuss strategies for reducing turnover and employee dissatisfaction

\section{Suggested Questions}

1. Which results are systematic or confirmed by the two methodologies used to evaluate causes of turnover?

2. $\quad$ Are there any distinct results between the methodologies used?

3. Would you recommend the use of more than one methodology when analyzing causes of turnover? Why?

4. From your point of view, which is the strongest cause of high undesirable turnover in "Ice Cream Deli"?

5. If you were on the consultant team, how would you commit senior management to lower the turnover rates?

6. If you were on the consultant team, what retention initiative would you suggest for this organization?

7. If you were the manager, what strategy would you implement in order to reduce high turnover in "Ice Cream Deli" and why?

8. Which is more expensive - the cost of doing necessary things to retain your most valuable people or the cost of losing and replacing those people? 